\title{
The Detection of Artificially Made Defects in Welded Joint with Ultrasonic Defectoscopy Phased Array
}

Daniel Dopjera, Miloš Mičian

University of Žilina, Faculty of Mechanical Engineering, Department of Technological Engineering. Univerzitná 1, Žilina 010 26. Slovak Republic. E-mail: daniel.dopjera@fstroj.uniza.sk, milos.mician@fstroj.uniza.sk

The article describes the fundamental physical principles of the ultrasonic defectoscopy Phased Array, which provides new possibilities in the non-destructive testing (NDT) of materials, especially of welded joints. There is a report from the ultrasonic testing of welded joint with ultrasonic flaw detector OmniScan MX2 from the company Olympus NDT. The artificial defects were designed in software ESBeamTool 5 from the company Eclipse Scientific, which simulates the geometrical ultrasonic beams spread. Then, ultrasonic testing was performed at the same welded joint with artificially made defects. At the end, data from both ultrasonic testing were evaluated. The same procedure will be used for the design of ultrasonic inspection TOFD (Time of Flight Diffraction) and Phased Array at welded joints of gas pipelines.

Keywords: NDT, Phased Array, ESBeamTool 5.

\section{Acknowledgement}

This article was created within the project solution no. 561/PG04/2011, which is supported by non-profit fund EkoFond, which founder is joint stock company SPP.

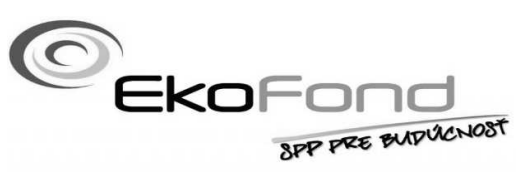

\section{References}

[1] ANDROŠOVÁ, Z., SKRBEK, B. (2012). The use of magnetic and ultrasonic structuroscopy for inspection of ADI/AGI castings. In Manufacturing technology, vol. 12, No. 13, pp. 93-97.

[2] ECLIPSE. 2013 (a). The company Eclipse Scientific. [Online]. 2013, [cit. 2013-08-23]. Internet: <http://www.eclipsescientific.com>.

[3] ECLIPSE. 2013 (b). Modelling and Inspection Design for NDT. [Online]. 2013, [cit. 2013-08-23]. Internet: <http://www.eclipsescientific.com/Software/Brochures/ESBeamTool.pdf>.

[4] KOŇÁR, R., MIČIAN, M., HOPKO, A. (2011) Analysis of boundary conditions for the simulation of welding at the repair of gas pipelines with steel sleeve. In. Communications, vol. 13, pp. 36-39.

[5] KOŇÁR, R., MIČIAN, M., (2012). Numerical simulation of residual stresses and distortions in butt weld in simulation programme SYSWELD. In Communications, vol. 14, pp. 49-54.

[6] MEŠKO, J., FABIAN, P., and et al. (2011). Shape of heat source in simulation program SYSWELD using different types of gases and welding methods. In Strojírenská technologie, No. 5, pp. 6-11.

[7] NOVÁK, P., MEŠKO, J., ŽMINDÁK, M., (2013) Finite element implementation of multi-pass fillet weld with phase changes. In: Manufacturing technology, vol. 13, No.1, pp.79-85.

[8] OLYMPUS. 2013 (a). The company Olympus NDT. [Online]. 2013, [cit. 2013-08-18]. Internet: <http://www.olympusims.com/cs>.

[9] OLYMPUS. 2013 (b). Phased Array Tutorial. [Online]. 2013, [cit. 2013-08-18]. Internet: <http://www.olympusims.com/cs/ndt-tutorials/phased-array>.

[10] OLYMPUS. 2012. Phased Array Testing Basic Theory for Industrial Applications. 2nd ed. Waltham, MA: Olympus NDT, 2012. 113 pp. DMTA-20003-01EN.

[11] OLYMPUS. 2007. Advances in Phased Array Ultrasonic Technology Applications. Waltham, MA: Olympus NDT, 2007.491 pp. ISBN 0-9735933-4-2.

[12] OLYMPUS. 2004. Introduction to Phased Array Ultrasonic Technology Applications. Waltham, MA: Olympus NDT, 2004. $351 \mathrm{pp}$. ISBN 0-9735933-0-X. 